\title{
Long Journey for Sevenpence: \\ Assisted Immigration to New Zealand from the United Kingdom 1947-1975.
}

\author{
Reviewed by A.J. Coleman
}

Long Journey for Sevenpence: Assisted Immigration to New Zealand from the United Kingdom 1947-1975.

Megan Hutching.

Victoria University Press, 1999.

The author, Megan Hutching, is the Oral Historian at the Historical Branch of the Department of Internal Affairs, so she is well suited to compiling a scholarly work from interviews and the answers to questionnaires, as well as from historical records. In case that should sound dull, be assured that the book is not.

The stuff of Ms Hutching's book is the recollections and observations of the able, energetic, and courageous young British people who made the decision to try their luck on the other side of the world. These assisted immigrants were almost entirely from the 'working class' for whom life in Britain following the Second World War was miserably grey. They did not make fortunes, but did materially improve themselves. They nearly all bought their own homes in New Zealand, which they would never have done in Britain, and raised healthy, well-nourished children. They rejoiced in our space and sunshine, and in the informality between management and staff in the workplace. It is surprising and sobering to read that one immigrant, whose skill was painting in lacquer, thought that New Zealanders were lazy. He used to finish his allocation of work by lunch-time.

Apart from the absorbing human interest in the book the author's observations on the New Zealand political scene during this period of nearly thirty years are highly interesting. Pressure from manufacturers for assisted immigration to relieve skills shortages was persistent: the Federation of Labour was at best lukewarm to immigration, citing - reasonably - the pressure which married immigrants placed upon accommodation and housing finance. In 1938 and again in 1957 the then Labour administration imposed import controls to conserve seriously depleted overseas funds. Had the outgoing administration been improvident, or had the incoming Labour administration spent up large in its first year, one wonders. In due course the 
subsequent National administrations began the long task of dismantling these controls. It seems that little has changed, in the political sense, between then and now.

There are some fascinating historical facts and some fascinating observations on the part of new New Zealanders. Dr O C Mazengarb urged Britain in 1954 - at the time of his report into juvenile delinquency in the Hutt Valley - to send 40,000 single women to this country! On the voyage out someone asked the table waiter in the relatively imposing dining room for tomato sauce (that dreadful, entrenched New Zealand habit!). The waiter, impassive, brought the sauce and skilfully dispensed it, but his disdain was evident, in that he kept it disguised in a white cloth, and 'neither exposed, or relinquished his grip, and ... quickly whisked it out of sight'.

One family was sent to Ohakune, and arrived at midnight. 'The next morning my mother was rather shocked when she walked into the back garden to find a mountain literally in the back yard!'. All the immigrants were shocked at the way in which, at dances, the girls cleaved to one side of the hall and the young men to the other. The 6 o'clock closing of hotels was described by one as 'joyfully appalling'. Another found New Zealand 'a living car and bus museum'. That, of course, was the consequence of import controls. Pity the immigrant lady who, in 1961, found she could not get the sapphire engagement ring she wanted 'because they had all sold out and new licences for more imports were not due for a couple of months'.

The absorbing content of the book is complemented by excellent photographs, tables, appendices and notes. The cover is particularly engaging. This book will have wide appeal, especially to those who were immigrants themselves, and to those who grew up in the years 1947-75.

\section{A.J. Coleman \\ Hastings}

